Click www.researchjournal.co.in/online/subdetail.html to purchase.

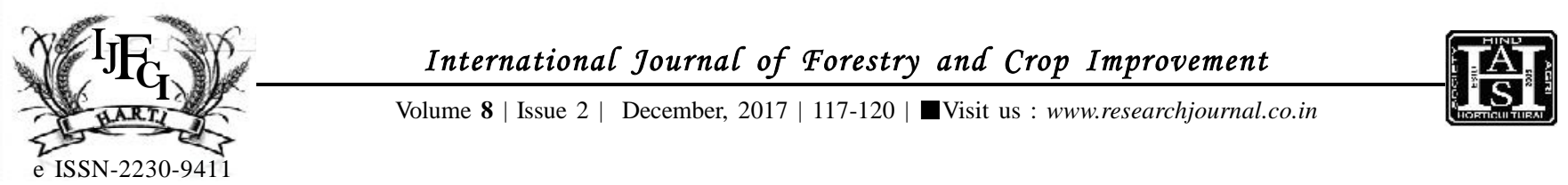

\title{
Evaluation of forage demonstrations to identify adoption gaps in oats production in limited water situations under RKVY project
}

\author{
S.M. KUMAWAT AND P.S. BAGENIA
}

\begin{abstract}
A study conducted in North West region of Rajasthan among 66 farmers sampled from four districts namely, Bikaner, Sriganganagar, Sikar and Hanumangarh. Among the districts 22 villages were selected randomly and all respondents were possessing limited irrigation resources. Improved package of practices for oats cultivation were maintained regarding forage demonstrations. The study was conducted for three years (i.e. 2011-12 to 2013-14) during Rabi season under RKVY project, governed by SKRAU, Bikaner and funded by Department of Agriculture and Farmer Welfare, GOI through Govt. of Rajasthan, Jaipur. Findings of the study revealed that increase in yield in demonstration plots due to adoption of improved package of practices was ranged between 31.6 to 55.56 per cent with mean per cent increase of $44.31 \%$ as compared to traditional practices of oats cultivation. In case of technology gap $154.50 \mathrm{q} /$ ha overall mean difference was observed whereas $75.00 \mathrm{q} / \mathrm{ha}$ yield an average extension gap and a wide technology gap of 42.0 per cent was recorded as a result of difference between technology generated by the researchers and its adoption at the farmers fields. However, the overall adoption index increased from 7.00 to 46.70 per cent due to intervention of the project. Study further highlighted that the comparison of cost: benefit ratio between traditional practice and the adoption of improved practices indicated that demonstrations technology proved twice profitable as compared to existing traditional practices. While an overall increase adoption index noted were 3.5 to $49.8,4.6$ to $34.6,12.9$ to $49.81,8.85$ to 63.9 , 4.9 to 34.2 and 7.3 to 48.4 per cent for the improved varieties, seed treatment, fertilizer and irrigation management, weed control and plant protection measures and cutting management practices, respectively.
\end{abstract}

KEY WORDS : Adoption index, Extension gap, Forage oats production, Potential yield, Technology gap, Water limited condition

HOW TO CITE THIS ARTICLE : Kumawat, S.M. and Bagenia, P.S. (2017). Evaluation of forage demonstrations to identify adoption gaps in oats production in limited water situations under RKVY project. Internat. J. Forestry \& Crop Improv., 8 (2) : 117-120, DOI: 10.15740/HAS/ IJFCI/8.2/117-120.

Article Chronical : Received : 10.10.2017; Revised : 05.11.2017; Accepted : 20.11.2017

MEMBERS OF RESEARCH FORUM

Address of the Correspondence : S.M. KUMAWAT, Centre for Forage Management, Agricultural Research Station (S.K.R.A.U.), BIKANER (RAJASTHAN) INDIA

Address of the Coopted Authors : P.S. BAGENIA, Centre for Forage Management, Agricultural Research Station (S.K.R.A.U.), BIKANER (RAJASTHAN) INDIA 